\title{
Rancang Bangun Host Sistem Mini SCADA Untuk Pengontrolan Beban Trafo 20 KV Pada Gardu Induk
}

\author{
Ikhwanto, R.A. Suwodjo Kusumoputro, Novi Azman \\ Program Studi Teknik Elektro, Fakultas Teknik dan sains, Universitas Nasional Jakarta. \\ Korespondensi: rask7260@yahoo.com
}

\begin{abstract}
ABSTARCT. In this era of globalization, the needs of remote control systems is increasing, where the system used is more sophisticated. Similarly, when a transformer operator in electrical substations, which will control and monitor the load transformer 20 $\mathrm{KV}$ is still done by hand. This will result in less efficient and optimal performance of the operator. We need a system that can control remotely. To overcome these problems, hence designed "Host Mini SCADA systems for controlling the load on $20 \mathrm{KV}$ transformer substations parent. With this system an operator can perform control and monitoring of the load transformer $20 \mathrm{KV}$, among others: Frequency, Current, Voltage, and Temperature. In addition, this system also can detect if the transformer is faulty. Monitoring and controlling performed remotely via SMS Gateway. This system consists of a PC (Personal Computer), which functions as process control and remote control units. GSM Modem serves to make the process of data transfer via SMS (Short Message Service). Software Visual Basic, a programming language used to create a program / software on Host mini SCADA system.
\end{abstract}

Keywords: Host Mini Systems SCADA, GSM Modem, SMS Gateway.

\section{PENDAHULUAN}

Berdasarkan hasil survey di sebuah gardu listrik induk yang berlokasi di Kuningan, penulis melihat bahwa cara kerja para teknisi / operator trafo listrik pada gardu tersebut masih dengan cara manual yaitu memantau kondisi beban trafo $20 \mathrm{KV}$ dengan cara datang langsung ke ruangan dimana gardu tersebut berada.

Demikian pula jika suatu kawasan mengalami gangguan pasokan listrik maka seorang operator harus dapat melakukan pemasokan dari gardu lain dengan cara menyalakan circuit breaker. Jika jarak circuit breaker jauh dari gardu tersebut maka seorang operator harus datang ke tempat dimana circuit breaker tersebut berada. Hal-hal tersebut diatas menjadikan kurang efisien dan kurang optimalnya kinerja operator. Untuk mengatasi masalah diatas, maka penulis merancang Host sistem mini SCADA (Supervisory Control and Data Acquisition) yang transfer datanya melalui SMS (Short Message Service). Dengan sistem ini seorang operator gardu listrik dapat melakukan pemantauan kondisi jaringan secara wireless.

\section{DASAR TEORI}

\section{SCADA (Supervisory Control and Data Acquisition)}

Definisi SCADA dalam arti harfiah adalah pengawasan (Supervisory), pengendalian (Control), dan pengambilan data (Data Acquisition). Sistem pengendalian berbasis SCADA banyak diterapkan dalam pengoperasian dan pengendalian sistem ketenagalistrikan ataupun industri. Sistem SCADA tidak dapat berdiri sendiri, namun harus didukung oleh berbagai macam infrastruktur seperti, master station, remote terminal unit, media telekomunikasi dan protokol komunikasi.

Sistem SCADA yang telah digunakan oleh industri selama ini. Dengan hanya mengandalkan indikator - indikator sederhana seperti lampu, meter analog, alarm suara (buzzer), seorang operator sudah dapat melakukan pengawasan terhadap mesin - mesin di pabrik. Seiring dengan perkembangan komputer yang semakin handal dalam beberapa dekade terakhir, maka komputer 
menjadi komponen penting dalam sebuah sistem SCADA modern. Sistem ini menggunakan komputer untuk menampilkan status dari sensor dan aktuator dalam suatu plant, menampilkannya dalam bentuk grafik, menyimpannya dalam database, bahkan menampilkannya melalui situs web. Pada umumnya komputer ini terhubung dengan sebuah pengendali misalnya : mikrokontroler, PLC (Proam Logic Controller) melalui sebuah protokol komunikasi tertentu (misal : fieldbus).

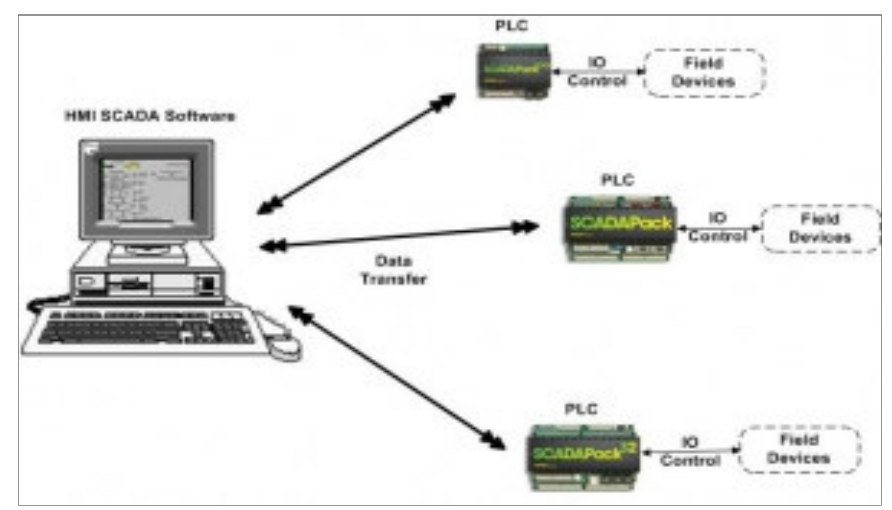

GAMBAR 1. Sistem Mini SCADA.

Personal Computer (PC) adalah suatu alat elektronika untuk mengolah data dan menggunakan suatu program tertentu dalam menghasilkan informasi. Fungsi PC disamping untuk menyimpan data, mengolah data, dan media komunikasi data juga bisa digunakan sebagai pengontrolan suatu alat (peripheral device). Sistem komputer dapat dibedakan dalam 3 kategori utama, yaitu: perangkat keras (hardware), perangkat lunak (software), dan operator / personil (brainware).

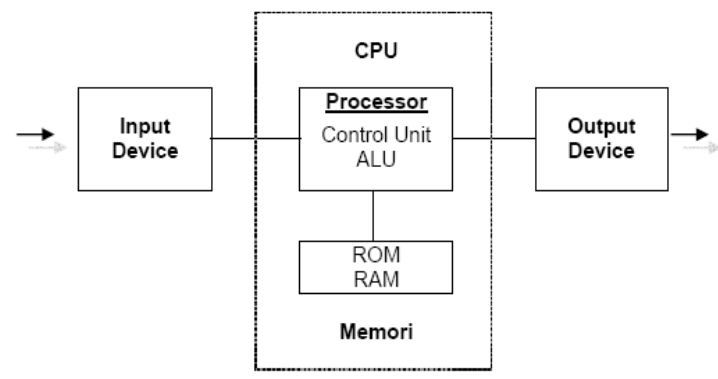

GAMBAR 2. Bagian Utama dari PC.

\section{Antar Muka Serial RS-232}

Antar muka serial RS 232 memberikan ketentuan logic level sebagai berikut:

- Logic 1 ( Keadaan 1 ) disebut "Mark" terletak antara - 3 Volt hingga -15 Volt

- Logic 0 (Keadaan 0 ) disebut "Space" terletak antara + 3Volt hingga +15 Volt

Daerah tegangan antara - 3 Volt hingga +3 Volt adalah Invalid level, yaitu tegangan yang tidak memiliki keadaan logic, sehingga daerah ini harus dihindari. Demikian pulsa selama RS 232 yang mendapat isyarat logic pada daerah negatif dari -15 Volt dan daerah lebih positif dari +15 Volt dapat merusak logic translatornya atau line driver pada saluran RS 232.

\section{Modem Seluler GSM}

Modem berasal dari singkatan (Modulator Demodulator). Modulator merupakan bagian yang menumpangkan sinyal informasi ke dalam sinyal pembawa (Carrier) yang siap untuk dikirimkan, sedangkan Demodulator adalah bagian yang memisahkan sinyal informasi (yang berisi data atau pesan) dari sinyal pembawa (carrier) yang diterima, sehingga informasi tersebut dapat diterima dengan baik. Modem merupakan penggabungan kedua-duanya, artinya modem adalah alat komunikasi dua arah yang media transfer datanya menggunakan gelombang radio, 
dan pengoperasiannya menggunakan SIM card GSM. Sebuah jaringan GSM dibangun dari beberapa komponen fungsional yang memiliki fungsi dan interface masing-masing yang spesifik. Secara umum jaringan GSM dapat dibagi menjadi tiga bagian utama yaitu mobile station, base station subsystem dan network subsystem.

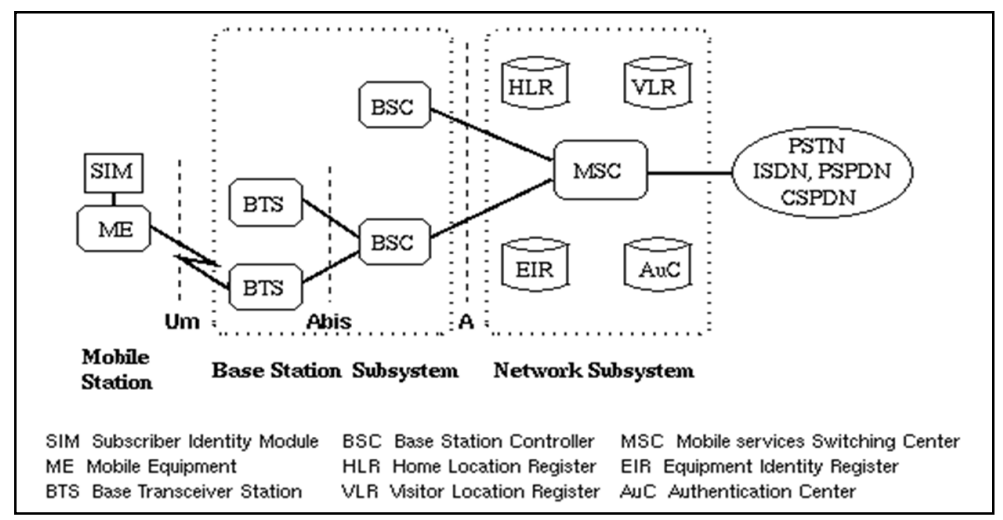

GAMBAR 3. Struktur Jaringan GSM.

\section{Short Message Service (SMS)}

SMS merupakan aplikasi GSM (Gobal Service Mobile) yang menyediakan layanan untuk mengirim dan menerima pesan pendek berupa huruf dan angka. Aplikasi ini hanya terbatas pada pengiriman dan penerimaan data berupa teks dengan panjang pesan antara 120 - 160 huruf bahkan ada yang sampai 765 huruf.

SMS point-to-point menyediakan mekanisme untuk mengirimkan pesan pendek (Short Message) ke dan dari piranti bergerak. Layanan ini menggunakan SMSC yang bertindak sebagai sistem simpan dan terusan untuk pesan pendek. Jaringan wireless akan menangani pengiriman pesan pendek antara SMSC dan piranti bergerak.

\section{Struktur Dasar Arsitektur Jaringan SMS}

Untuk implementasi layanan SMS, operator menyediakan apa yang disebut dengan SMSC (SMS Center). Secara fisik SMSC dapat berupa suatu PC biasa dengan kemampuan interkoneksi dengan jaringan SMS.

Salah satu implementasi SMSC Open Source adalah Kannel, yang dapat digunakan untuk membangun WAP (Wireless Application Protocol) dan SMS Gateway. SMSC secara optional bisa juga terkoneksi dengan jaringan X.25 atau TCP/IP, sehingga dapat juga dibangun berbagai aplikasi internet yang mempunyai hubungan dengan jaringan GSM. Arsitektur dasar jaringan SMS dapat dilihat pada gambar 4.

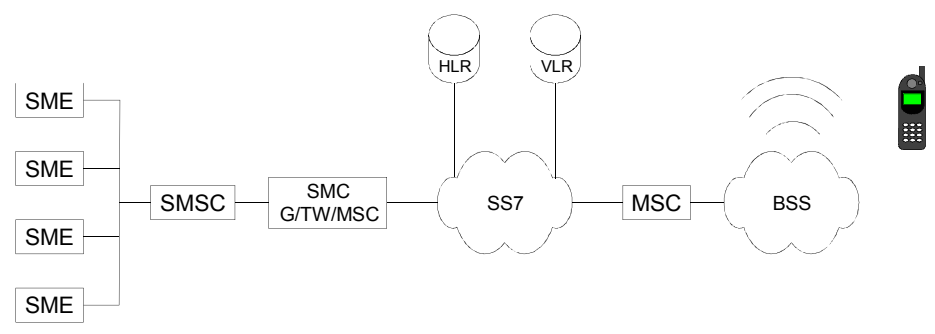

GAMBAR 4. Arsitektur Jaringan SMS.

Database adalah kumpulan data yang saling terkait dan terkelola dalam satu unit. Item data tersebut akan menjadi penting jika diolah menjadi suatu data informasi. Database sebagai kumpulan data dalam satu tabel atau lebih. Baris dalam tabel berisi satu unit data yang disebut record, sedangkan pada kolom berisi atribut dari record yang disebut field. 
Visual Basic adalah suatu bahasa pemograman yang sering disebut sebagai sarana (Tool) untuk menghasilkan program-program aplikasi berbasis windows. Dalam pengembangan aplikasi, Visual Basic menggunakan pendekatan Visual untuk merancang user interface dalam bentuk form, sedangkan untuk kodingnya menggunakan bahasa Basic yang mudah dipelajari.

\section{PERANCANGAN SISTEM}

Prinsip kerja dari sistem ini secara umum dapat dilihat pada gambar 5. Sistem ini terdiri dari Host dan beberapa remote unit. Dalam sistem ini Host akan mengirimkan perintah ke remote unit melalui SMS (Short Message Service), untuk memantau dan mendapatkan informasi kondisi dari remote unit antara lain : frekuensi, arus, Tegangan, dan Suhu. Selain itu remote unit juga akan mengirimkan informasi ke Host apabila terjadi gangguan.

Sistem ini juga dilengkapi dengan form login untuk pengamanan. Jadi seorang operator yang memiliki username dan password, dapat melakukan login dahulu sebelum masuk pada program tersebut. Setiap user mempunyai username dan password yang berbeda-beda dan access setiap user akan dimasukkan ke database.

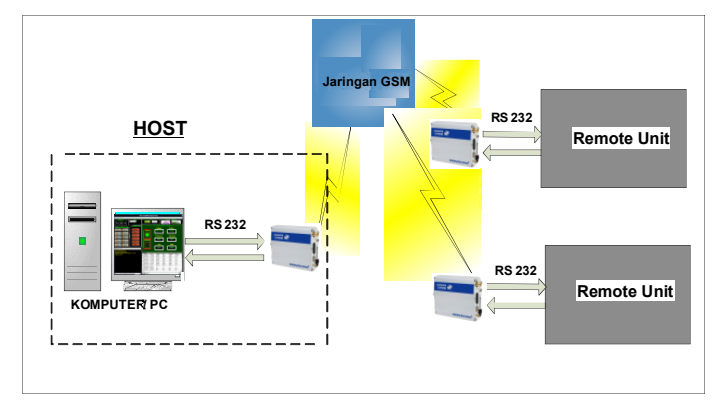

GAMBAR 5. Diagram Blok Host Mini SCADA.

Secara umum ada beberapa manfaat yang diperoleh dari pemakaian program Visual Basic, diantaranya dipakai dalam membuat program aplikasi berbasis windows, kemudian dipakai dalam membuat obyek-obyek pembantu program, seperti fasilitas Help, kontrol ActiveX, aplikasi Internet, dan sebagainya serta digunakan untuk menguji program (Debugging) dan menghasilkan program akhir EXE yang bersifat Executable, atau dapat langsung dijalankan.

\section{Rangkaian Interface RS-232}

Agar host dapat berkomunikasi dengan remote unit melalui port serial maka harus menggunakan rangkaian RS-232. Rangkaian ini digunakan sebagai penghubung antara PC dengan Modem seluler GSM, yang berfungsi untuk merubah level tegangan TTL menjadi level tegangan RS-232 maupun sebaliknya.

\section{Modem GSM}

Pada bagian ini modem GSM berfungsi sebagai penghubung antara Host dengan Remote Unit melalui jaringan GSM, modem yang digunakan adalah favecome Fastrack Supreme 10 yang beroperasi pada frekuesi $15200 \mathrm{MHz}$. Untuk melakukan komunikasi dengan modem GSM, program ini menggunakan instruksi "AT Command", yang merupakan standar bahasa yang digunakan untuk komunikasi dengan modem termasuk Handphone, instruksi standar ini harus dikonversikan kedalam kode ASCII (American Standard Code for Information Interchange) agar dapat terbaca dan dimengerti oleh modem GSM. Berikut ini adalah contoh beberapa daftar $A T$ Command yang sering digunakan sebagai berikut,

$\begin{array}{ll}\text { ATA } & \text { Answer Command } \\ \text { ATD } & \text { Dial Command } \\ \text { ATH } & \text { Hang Up Call } \\ \text { AT+CMGL } & \text { List Messages } \\ \text { AT+CMGR } & \text { Read Message } \\ \text { AT+CMGS } & \text { Send Message }\end{array}$




\section{Structured Query Language (SQL)}

Structured Query Language (SQL) merupakan bahasa standar yang dipergunakan untuk pengelolaan database. Database dan SQL sangat erat kaitannya, dimana dengan SQL program aplikasi mengelola database seperti membuat tabel, menambah, menghapus dan juga menampilkan record dari suatu database yang diinginkan sesuai dengan kriteria tertentu.

\section{SMS Gateway.}

SMS Gateway merupakan program aplikasi yang digunakan sebagai interface antara Host dengan modem selular GSM. Semua SMS yang dikirim dan diterima oleh Host harus melewati program aplikasi ini.

\section{Microsoft Component Object Model (MSCOM)}

Microsoft Component Object Model merupakan komponen yang terdapat dalam program aplikasi visual basic, Komponen ini berfungsi untuk berkomunikasi antara Host dengan remote unit, melalui port serial yang ada di PC.

\section{Proses pengiriman data melalui SMS (Short Message Service)}

Proses pengiriman data ini menggunakan fasilitas port dengan menggunakan transmisi komunikasi data RS-232 dan sebuah rangkaian interface RS-232. Pada proses pengiriman data ini faktor yang terpenting adalah settingan pada COM (Component Object Model). Pada Visual Basic.6 telah disediakan sebuah control COM yang berfungsi untuk melakukan proses pengiriman dan penerimaan data diluar program aplikasi. Kontrol COM ini harus di-set terlebih dahulu untuk menentukan jenis port yang digunakan, baud rate, input dan out buffer, dan lainlain. Contoh potongan program seting COM:

$$
\begin{aligned}
& \text { With } \text { Comm } \\
& \text { CommPort }=1 \\
& \text { Settings }=" 115200, N, 8,1 " \\
& \text {.InBufferSize }=1024 \\
& \text {.OutBufferSize }=1024 \\
& \text {.PortOpen }=\text { True }
\end{aligned}
$$

End With

\section{Perancangan Layar Tampilan}

Tahap perancangan layar ini sangat penting dalam membuat suatu aplikasi, dengan desain tampilan yang menarik sehingga akan membuat pemakai tidak jenuh dan nyaman. Desain layar tampilan juga harus memiliki tata letak tombol yang bagus dan memudahkan pemakai dalam mengoperasikannya.

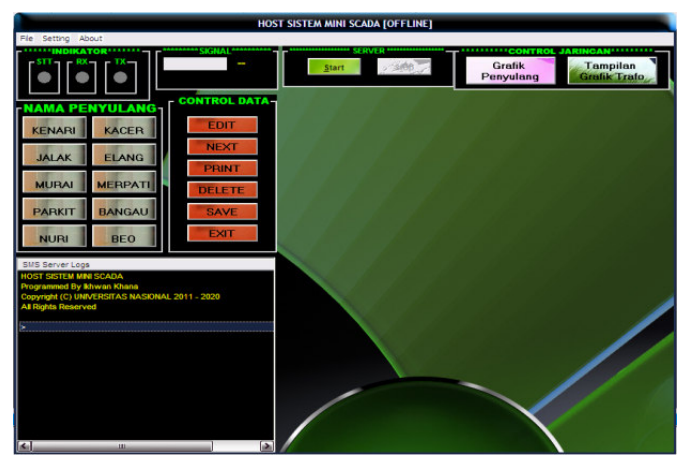

GAMBAR 6. Tampilan Layar Menu Utama.

\section{Pembuatan perangkat lunak}

Untuk mempermudah dalam pembuatan listing program kita harus membuat diagram alir (Flowchart) pada sistem yang akan kita bangun, karena dengan membuat flowchart kita dapat 
menelusuri program secara rinci apabila terjadi kesalahan, sehingga program dapat berjalan dengan lancar yang sesuai dengan perancangan. Pembuatan program perangkat lunak (Software) ini terbagi menjadi dua bagian, antara lain :

\section{Pembuatan perangkat lunak pada sisi Host.}

Langkah awal program ini adalah melakukan pengecekan koneksi modem apakah sudah terkoneksi dengan komputer atau belum. Jika sudah terjadi koneksi, selanjutnya Host akan melakukan pengiriman data ke remote unit melalui SMS, untuk mengetahui kondisi beban trafo $20 \mathrm{KV}$ pada gardu induk, antara lain : Frekuensi, Arus, Tegangan Dan Suhu. Data yang dikirim oleh Host berupa karakter yaitu : "F" untuk data frekuensi, "T" untuk Tegangan, "A" untuk arus dan "S" untuk suhu, kemudian data tersebut akan diterima oleh remote unit dan dibaca unuk di cocokan dengan database yang ada pada remote unit. Apabila data tersebut cocok degan database, maka remote unit akan mengirimkan data sesuai dengan karakter yang dikirim oleh Host. Data yang dikirim oleh remote unit akan ditampilkan ke layar monitor dan disimpan ke dalam database. Algoritma program Host sistem mini SCADA ini di sajikan dalam bentuk flowchart seperti gambar 7.

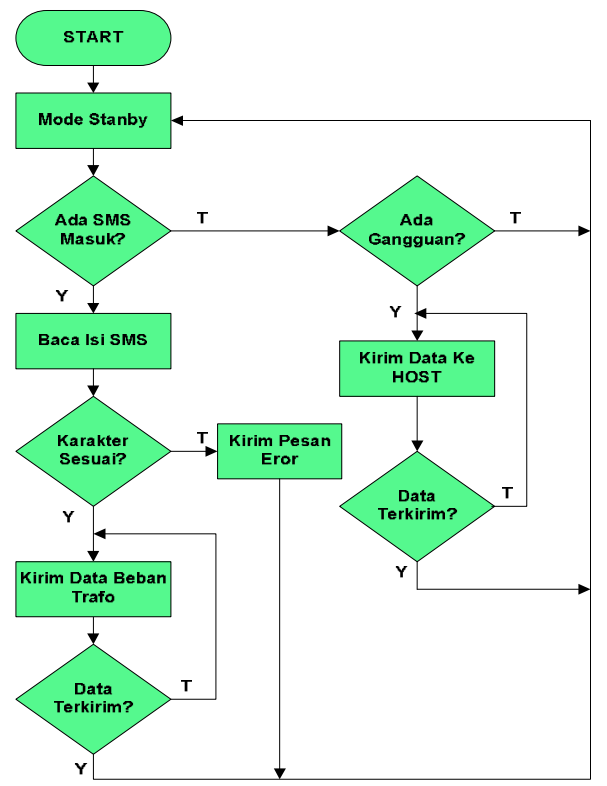

GAMBAR 7. Flowchart Alur Program Remote Unit.

\section{Pembuatan perangkat lunak pada sisi remote unit.}

Cara kerja pada sistem remote unit ini yaitu sistem ini akan melakukan kondisi standby untuk menunggu SMS yang dikirim dari host, kemudian sistem ini akan membaca isi SMS tersebut dan mencocokan dengan database yang ada pada remote unit. Jika isi SMS tersebut sama dengan nilai yang ada di database, maka sistem ini akan mengirimkan data yang sesuai dengan kata kunci yang dikirim oleh host. Dan apabila data yang dikirim host tidak sesuai dengn database, maka sistem ini akan mengirimkan pesan error. Disamping itu, sistem ini juga dapat mengirimkan informasi apabila beban trafo $20 \mathrm{KV}$ pada gardu induk mengalami gangguan, sehingga host dapat mendeteksi adanya gangguan tersebut dan mengeksekusinya. Algoritma program remote unit ini di sajikan dalam bentuk flowchart sebagai berikut :

\section{PENGUJIAN SISTEM}

\section{Pengujian komputer dengan modem melalui hyperterminal}

Pengujian ini dilakukan untuk mengetahui apakah hubungan modem GSM dengan computer berhasil atau tidak. Langkah-langkah untuk pengujian ini sebagai berikut, modem GSM dihubungkan dengan komputer dengan menggunakan kabel RS-232 melalui COM 1. kemudian 
pada komputer buka program hyperterminal yang ada di windows (Start, Programs Accessories, Communication, Hyperterminal)

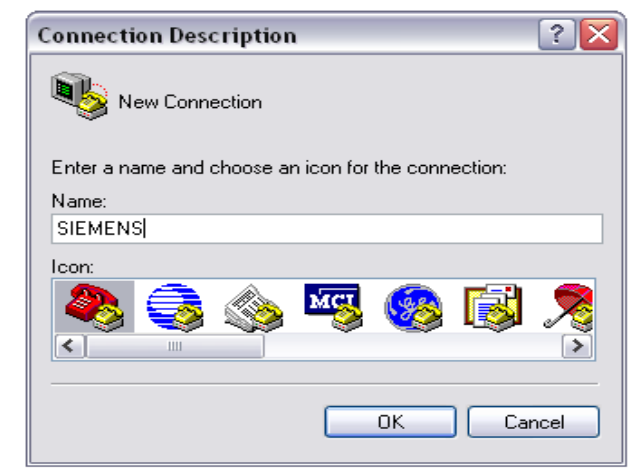

GAMBAR 8. Tampilan Koneksi awal Hyperterminal.

langkah selanjutnya adalah, pada jendela Connection Description ditulis nama koneksinya kemudian klik OK, sehingga akan dilanjutkan dengan jendela Connect To, pada Connect using diisikan port serial yang digunakan yaitu COM1.

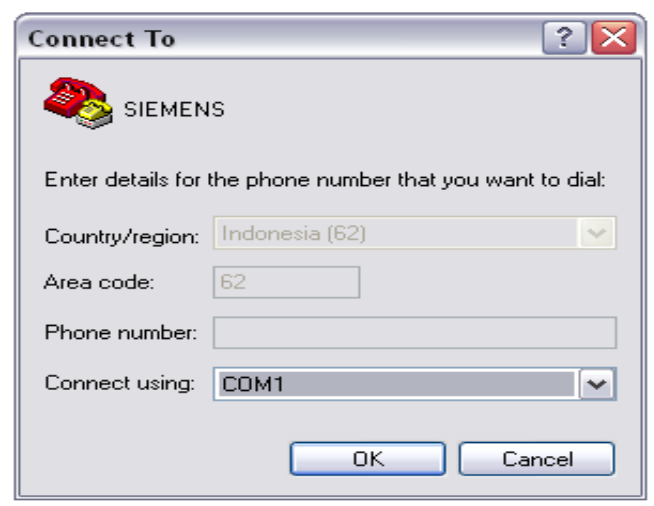

GAMBAR 9. Tampilan Untuk Memilih Port Serial.

Kemudian lanjutkan dengan jendela COM1 Properties, pada bagian ini dimasukkan parameter komunikasi yang diperlukan, seperti pada gambar 10.

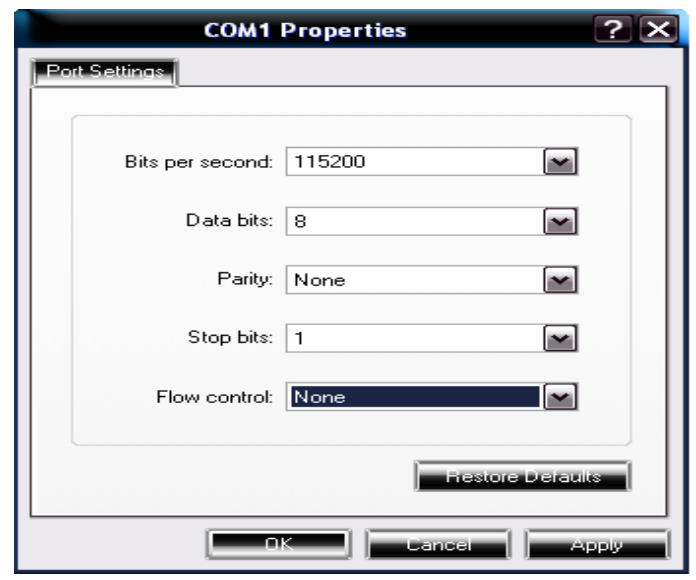

GAMBAR 10. Tampilan Parameter Komunikasi. 
Hyperterminal siap melakukan komunikasi dengan modem Setelah masuk ke Hyperterminal seperti terlihat pada gambar 10 lalu ketik "AT+CMGR=1"untuk melihat isi SMS kemudian tekan enter, jika muncul tulisan "OK" berarti hubunga berhasil dan kalau muncul tulisan "ERROR" maka hubungan gagal.

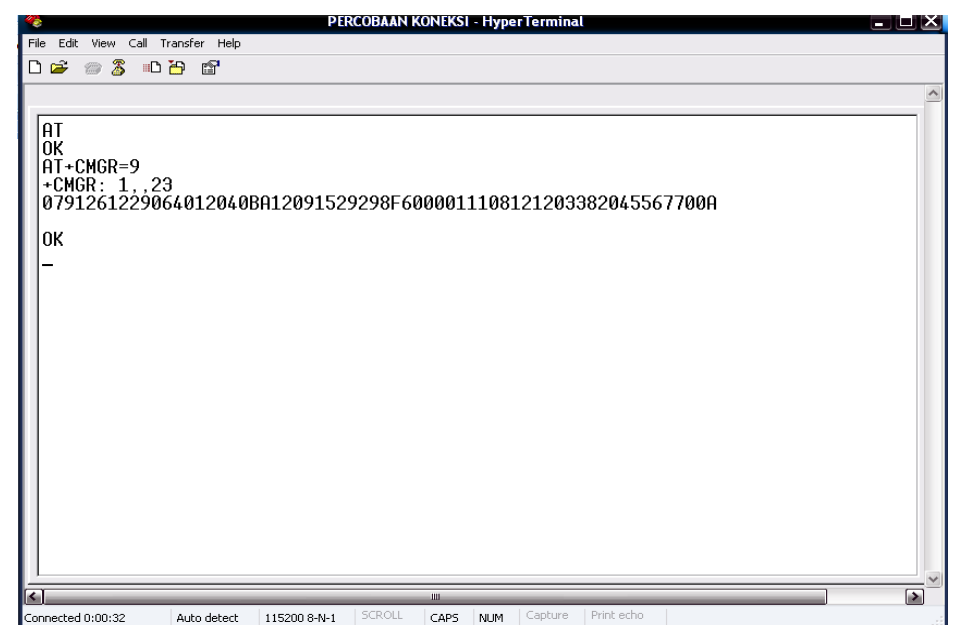

GAMBAR 11. Tampilan Jika Tidak Ada Kesalahan Koneksi.

\section{Pengujian Pengoperasian Host.}

Setelah pengujian antara komputer dengan modem selesai, selanjutnya adalah melakukan pengujian pada sistem program Host yaitu dengan cara login terlebih dahulu untuk menuju form тепи.

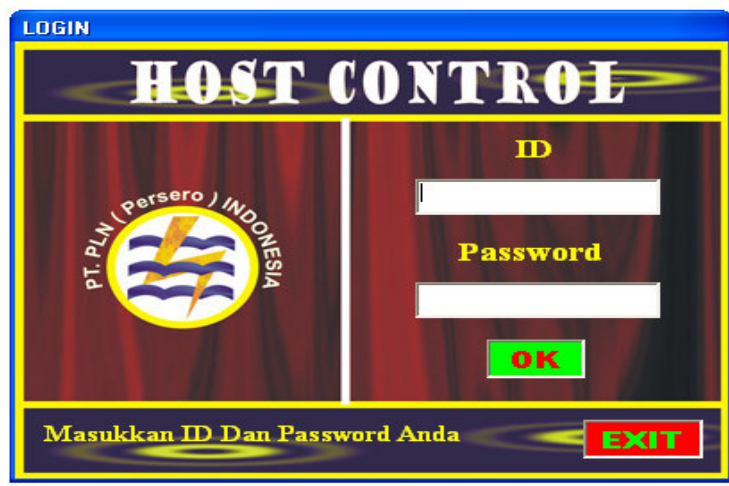

GAMBAR 12. Tampilan Login.

Setelah user name dan password diisi maka tombol login sistem di-klik untuk mengaktifkan sistem. Apabila terjadi kesalahan dalam mengisi username atau password maka akan muncul pesan seperti terlihat pada gambar dibawah ini :

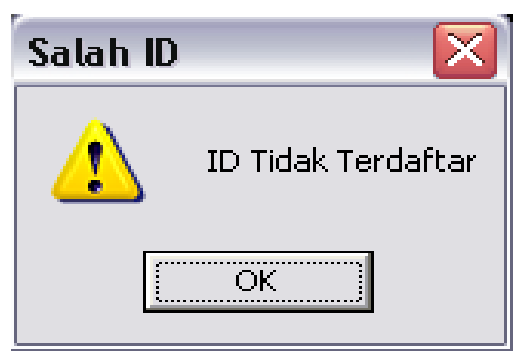

GAMBAR 13. Tampilan Pesan Kesalahan Login. 
Sedangkan apabila username dan password yang diisi benar, maka akan muncul tampilan seperti terlihat pada gambar 14 .

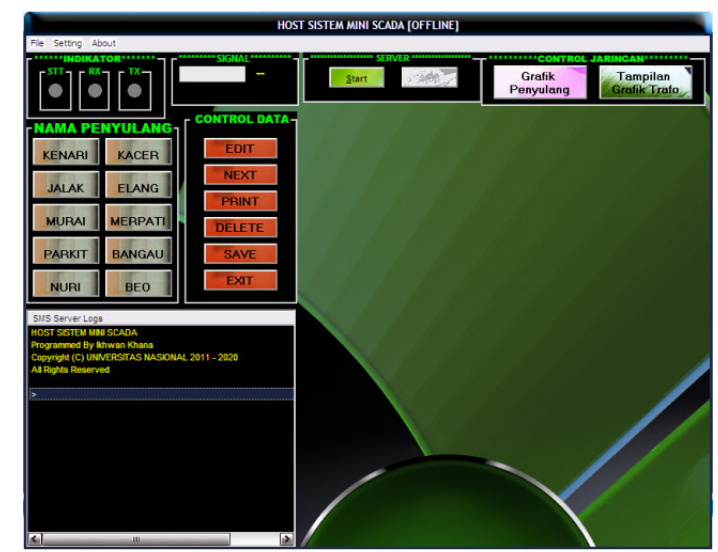

GAMBAR 14. Tampilan Form Menu Utama.

Jika koneksi antara host dengan remote unit berhasil maka langkah selanjutnya adalah mengirimkan kode - kode untuk meminta data dari remote unit seperti : kode " $F$ " untuk kode frekuensi, "T" untuk kode tegangan, "A" untuk kode Arus, "S" untuk kode suhu, kemudian data tersebut akan disimpan ke dalam database.

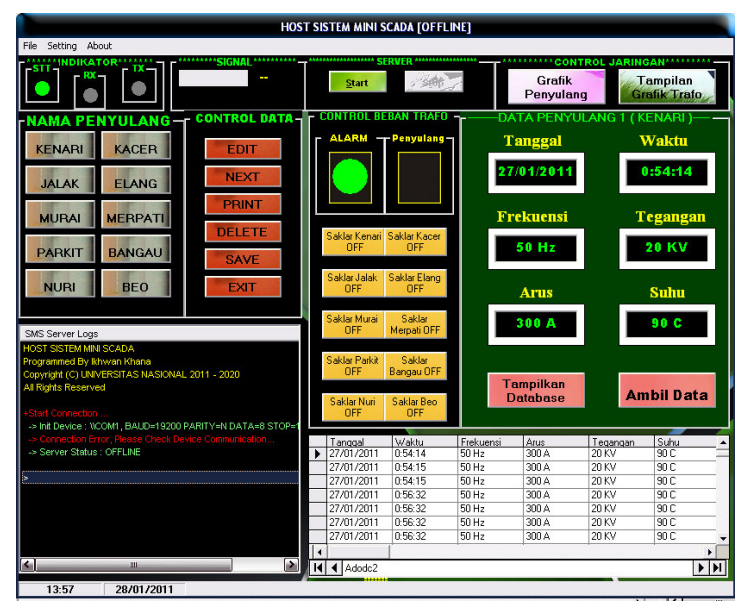

GAMBAR 15. Tampilan Penerimaan data Dari Remote Unit.

Dari percobaan pengiriman data tersebut, maka dapat dilihat pada tabel 1.

TABLE 1. Hasil Pengujian Sistem.

\begin{tabular}{|c|c|c|c|c|c|}
\hline Nemer Tujuan & $\begin{array}{c}\text { Nama } \\
\text { Penvulang }\end{array}$ & $\begin{array}{c}\text { Data Dari } \\
\text { HOST }\end{array}$ & $\begin{array}{l}\text { Data Yang } \\
\text { Diterima }\end{array}$ & Waktu & Keterangan \\
\hline \multirow[t]{4}{*}{087889415025} & Kenari & "F" & $50 \mathrm{HZ}$ & $00: 00: 13$ & Sukses \\
\hline & 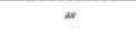 & "A" & $300 \mathrm{~A}$ & $00: 00: 13$ & Sukses \\
\hline & “ & "T" & $20 \mathrm{KV}$ & $00: 00: 13$ & Sukses \\
\hline & 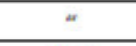 & "S" & $90 \mathrm{C}$ & $00: 00: 13$ & Sukses \\
\hline \multirow[t]{4}{*}{085715369720} & Jalak & "F" & $50 \mathrm{HZ}$ & $00: 00: 17$ & Sukses \\
\hline & ${ }^{\alpha}$ & "A" & $300 \mathrm{~A}$ & $00: 00: 17$ & Sukses \\
\hline & 4 & "T" & $20 \mathrm{KV}$ & $00: 00: 17$ & Sukses \\
\hline & 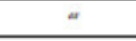 & "S" & $90 \mathrm{C}$ & $00: 00: 17$ & Sukses \\
\hline
\end{tabular}

Setelah semua data diterima oleh host maka langkah selanjutnya adalah menyimpan data tersebut ke database, data tersebut akan ditampilkan sebagai laporan dengan menggunakan Data Report. 


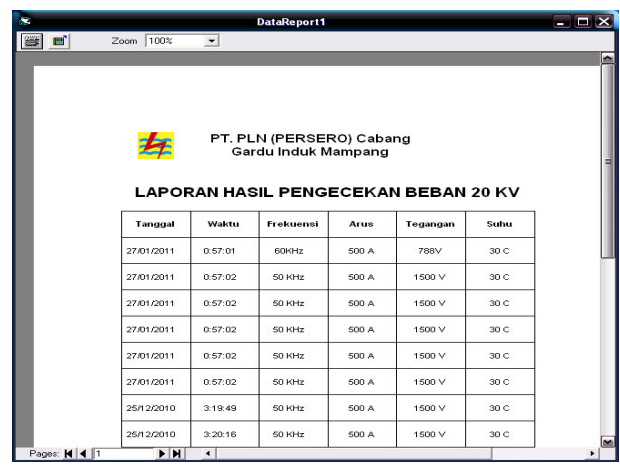

GAMBAR 16. Tampilan DataReport.

Selanjutnya apabila terjadi gangguan, maka remote unit akan mengirimkan informasi ke Host. Kemudian lampu indikator akan menyala diikuti dengan suara (buzzer) dan posisi penyulang yang mengalami gangguan akan ditampilkan.

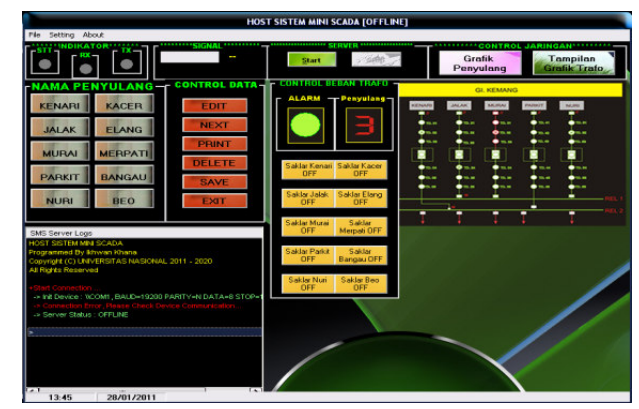

GAMBAR 17. Tampilan apabila terjadi gangguan.

\section{KESIMPULAN}

Berdasarkan pengujian - pengujian yang telah dilakukan terhadap sistem ini, maka diperoleh bahwa berdasarkan hasil pengujian fungsi masing-masing fitur, Host dapat bekerja dengan baik sesuai dengan perancangan.

Kemudian kecepatan pengendalian dan pemantauan terhadap Remote Unit sangat bergantung kepada kondisi jaringan selular GSM.

\section{DAFTAR PUSTAKA}

[1] Agus Harya Maulana, ST, "Fungsi SCADA (Supervisory Control and Data Acquisition)", Jakarta, 2005.

[2] Adi kurniadi, "Pemograman Mikrosoft Visual Basic 6.0", PT Elex Media Komputindo, Jakarta, 1999.

[3] Harianto Kristanto, "Konsep Perancangan Database", PT Elex Media Komputindo, Yogyakarta, 1994.

[4] Khang, Bustam, Ir. "Trik Pemrograman Aplikasi Berbasis SMS”, Elex Media Komputindo, Jakarta, 2002.

[5] Suhata,ST. "VB Sebagai Pusat Kendali Peralatan Elektronik", PT Elex Media Komputindo, Jakarta, 2004.

[6] Subari \& Yuswanto, "Panduan Lengkap Pemograman Visul Basic 6.0", Cerdas Pustaka Publisher, Jakarta, 2008.

[7] Uus Rusmawan, "Mengolah Database dengan SQL dan Crystal Report dalam Visial Basic 6.0”, PT Elex Media Komputindo, Jakarta, 2004. 